\title{
High-resolution record of Northern Hemisphere climate extending into the last interglacial period
}

\author{
North Greenland Ice Core Project members* \\ ${ }^{*}$ A full list of authors appears at the end of this paper
}

Two deep ice cores from central Greenland, drilled in the 1990s, have played a key role in climate reconstructions of the Northern Hemisphere, but the oldest sections of the cores were disturbed in chronology owing to ice folding near the bedrock. Here we present an undisturbed climate record from a North Greenland ice core, which extends back to 123,000 years before the present, within the last interglacial period. The oxygen isotopes in the ice imply that climate was stable during the last interglacial period, with temperatures $5^{\circ} \mathrm{C}$ warmer than today. We find unexpectedly large temperature differences between our new record from northern Greenland and the undisturbed sections of the cores from central Greenland, suggesting that the extent of ice in the Northern Hemisphere modulated the latitudinal temperature gradients in Greenland. This record shows a slow decline in temperatures that marked the initiation of the last glacial period. Our record reveals a hitherto unrecognized warm period initiated by an abrupt climate warming about 115,000 years ago, before glacial conditions were fully developed. This event does not appear to have an immediate Antarctic counterpart, suggesting that the climate see-saw between the hemispheres (which dominated the last glacial period) was not operating at this time.

The two deep ice cores drilled at the beginning of the 1990s in central Greenland (GRIP ${ }^{1-3}$ and GISP2 $2^{4,5}$, respectively 3,027 $\mathrm{m}$ and 3,053 $\mathrm{m}$ long) have played a key role in documenting rapid climate changes during the last glacial period. However, it quickly became clear that the bottom $10 \%$ of at least one (and most probably both) of these ice cores ${ }^{4,6-9}$ was disturbed owing to ice folding close to the bedrock. The Central Greenland ice core records are fully reliable climate archives back to 105,000 years before present ( $105 \mathrm{kyr}$ BP), but the disturbances mean that no reliable Northern Hemisphere ice core record of the previous interglacial (the Eemian climatic period) was known to exist in the Northern Hemisphere.

This situation motivated the search for a new drilling site where undisturbed ice from the last interglacial period ${ }^{10}$, and even from the previous glacial period, would be accessible ${ }^{11}$. The North Greenland Ice Core Project (NGRIP) site, located at $75.10^{\circ} \mathrm{N}$ and $42.32{ }^{\circ} \mathrm{W}$ with an elevation of $2,917 \mathrm{~m}$ and an ice thickness of $3,085 \mathrm{~m}$ (Fig. 1), was selected on the basis of three criteria that, when satisfied together, should produce dateable ice older than that found in central Greenland: a position on a ridge to reduce deformation by ice flow, flat bedrock, and a lower precipitation rate. The present accumulation rate is $0.19 \mathrm{~m}$ ice equivalent $\mathrm{yr}^{-1}$, the annual mean temperature is $-31.5^{\circ} \mathrm{C}$, and the ice near the base originates $50 \mathrm{~km}$ upstream of the ice ridge in the direction of Summit ${ }^{12}$. The NGRIP drilling started in 1996, and bedrock was reached in July 2003.

\section{Dating of the NGRIP climate record}

The climate record of the oxygen isotopic composition of the ice $\left(\delta^{18} \mathrm{O}\right)$ from the NGRIP ice core is shown in Fig. 2 (and is available as Supplementary Information). In cold glaciers where the basal ice temperature is below freezing, the annual ice layers typically thin towards zero thickness close to bedrock, and flow induced disturbances can limit the usefulness of the deepest part of ice cores ${ }^{13}$. In contrast, at NGRIP high rates of basal ice melting, estimated to be $7 \mathrm{~mm} \mathrm{yr}^{-1}$ (refs 12, 14), remove the bottom layers, greatly restricting the thinning of the layers and the possibility of ice disturbances. Whereas the present-day accumulation is 15\% lower at NGRIP than at GRIP, NGRIP annual layer thicknesses at $105 \mathrm{kyr}$ BP (depth $2,900 \mathrm{~m}$ ) are of the order of $1.1 \mathrm{~cm}$, twice that of GRIP ice of this age.

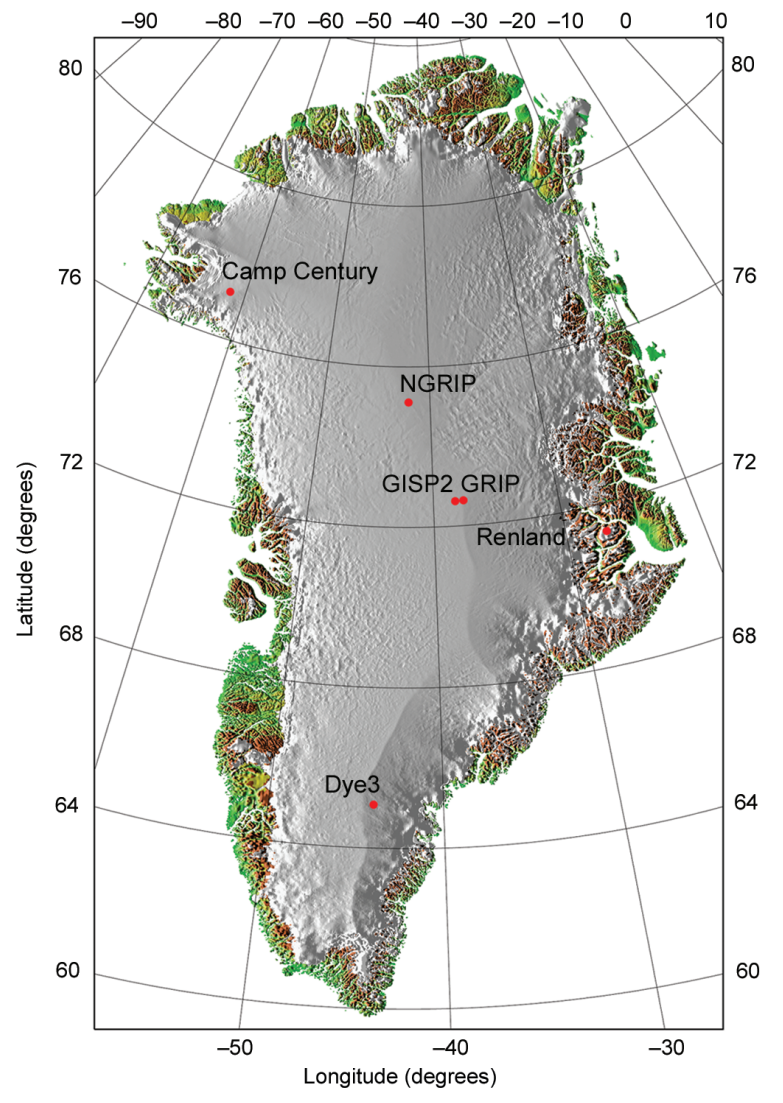

Figure 1 Map of Greenland, showing the locations of the deep ice core drilling sites. The sites GRIP $\left(72.5^{\circ} \mathrm{N}, 37.3^{\circ} \mathrm{W}\right)$, GISP2 $\left(72.5^{\circ} \mathrm{N}, 38.3^{\circ} \mathrm{W}\right)$, NGRIP $\left(75.1^{\circ} \mathrm{N}, 42.3^{\circ} \mathrm{W}\right)$, Camp Century $\left(77.2^{\circ} \mathrm{N}, 61.1^{\circ} \mathrm{W}\right)$, Dye3 $\left(65.2^{\circ} \mathrm{N}, 43.8^{\circ} \mathrm{W}\right)$ and Renland $\left(71.3^{\circ} \mathrm{N}, 26.7^{\circ} \mathrm{W}\right)$ are marked. The Greenland map was provided by S. Ekholm, Danish Cadastre. 
The NGRIP isotopic record covers the Holocene, the entire last glacial period, and part of the Eemian period. The 24 abrupt and climatic warm Dansgaard-Oeschger (DO) events, or Greenland interstadials (GIS), initially numbered in the GRIP record ${ }^{1,2}$ are very clearly identified (Fig. 2a, b), as are the climatic cold Greenland stadials (GS) that follow the DO events. The NGRIP core has been cross-dated to the GRIP core ss09sea chronology ${ }^{15}$ down to $105 \mathrm{kyr}$ BP using the high-resolution ice isotope profiles and volcanic events found in the ECM and DEP records $s^{5,16}$. Older ice is cross-dated to the Antarctic Vostok ice core records by using concentrations of methane and $\delta^{18} \mathrm{O}$ of the entrapped air ${ }^{9,17-22}$. To determine if deep ice folding is a problem at NGRIP, we concentrate on the period corresponding to the marine isotope stage (MIS) $5 \mathrm{~d} / 5 \mathrm{c}$ transition dated around $105 \mathrm{kyr}$ BP at Vostok (GT4 timescale). From methane and $\delta^{15} \mathrm{~N}$ air measurements, we confirm that this transition is the counterpart of the Northern Hemisphere stadial $25^{18,21,23}$ that ends with the abrupt onset of DO 24 at the NGRIP depth of 2,940 m (Fig. 3). At this depth, methane concentrations in air exhibit a rapid increase from 450 to 650 p.p.b.v., a shift which is also observed in the Vostok data ${ }^{24}$ (Fig. 3), and the $\delta^{15} \mathrm{~N}$ air signal, measured with a resolution of better than $100 \mathrm{yr}$, shows a rapid increase typical of DO events, resulting from thermal and gravitational fractionation processes. The increase in $\delta^{15} \mathrm{~N}$ and in methane concentration over the warming of DO 24 are both located $7 \mathrm{~m}$ deeper in the ice core than the corresponding $\delta^{18} \mathrm{O} \operatorname{transition}^{25-27}$ (Fig. 3). This reflects the typical depth shift, or gas-age/ice-age difference, expected with normal firnification processes and later thinning through ice flow ${ }^{28}$. This supports our contention that the bottom ice is undisturbed by folding or ice mixing. We note that similar investigations on the GRIP core have confirmed that this record is indeed disturbed at the time of the $5 \mathrm{~d} / 5 \mathrm{c}$ transition $^{7,18}$, as in that core the isotope and gas transitions are located at the same depth.

Below DO 19 the NGRIP record is compared to the planktonic oxygen isotope record from marine core MD95-2045 drilled on the
Iberian margin ${ }^{29}$ (Fig. 4). On the basis of strong similarities between these two records and ice modelling as well as $\delta^{18} \mathrm{O}$ air measurements on the deepest parts of the core compared with Vostok, the basal part of the NGRIP record is dated to $123 \mathrm{kyr}$ BP. Owing to the basal melting, the annual layer thickness of the ice from 2,700 to $3,085 \mathrm{~m}$ ( 90 to $123 \mathrm{kyr} \mathrm{BP}$ ) thins much less than in the case of no melting, further making dating straightforward. At these depths, the depth scale is almost linearly proportional to time. Thus, we feel confident in interpreting the ice isotopic record at NGRIP as the first Northern Hemisphere ice core record of a highly detailed, undisturbed climate record of the late Eemian and the inception of the last glacial period.

\section{Climate record of the late Eemian period}

We first examine the implications arising from the relatively high (warm) and stable Eemian ice isotopic values found in the bottom $85 \mathrm{~m}$ of the ice core. As noted above, the annual layers are unusually thick, 1.0 to $1.6 \mathrm{~cm}$, through this period of glacial interception and the latter part of the Eemian period, allowing a very detailed look at this key climatic period. The maximum isotopic value of $-32 \%$ found for the Eemian in the NGRIP core corresponds to the highest values found in the GRIP and GISP2 ice cores. Although these other cores have disturbed chronologies for ice older than $105 \mathrm{kyr}$ BP, they do contain Eemian age ice ${ }^{15,18}$, and the maximum isotopic values can be assumed to represent the warmest Eemian climate ${ }^{30}$. Because both the present interglacial isotopic values $(-35 \%)$ and the Eemian values are similar in the GRIP, GISP2, and NGRIP ice, we infer that the ice from the bottom of the NGRIP core has sampled the warmest part of Eemian climate. This maximum isotopic value is $3 \%$ o higher than the present value, and if attributed solely to temperature, implies at least a $5 \mathrm{~K}$ warmer temperature in the Eemian than at present ${ }^{30-33}$. It is notable that the $3 \%$ isotopic value difference between the present and the Eemian period seen at NGRIP, GRIP and GISP2 is also found in northern Greenland ice

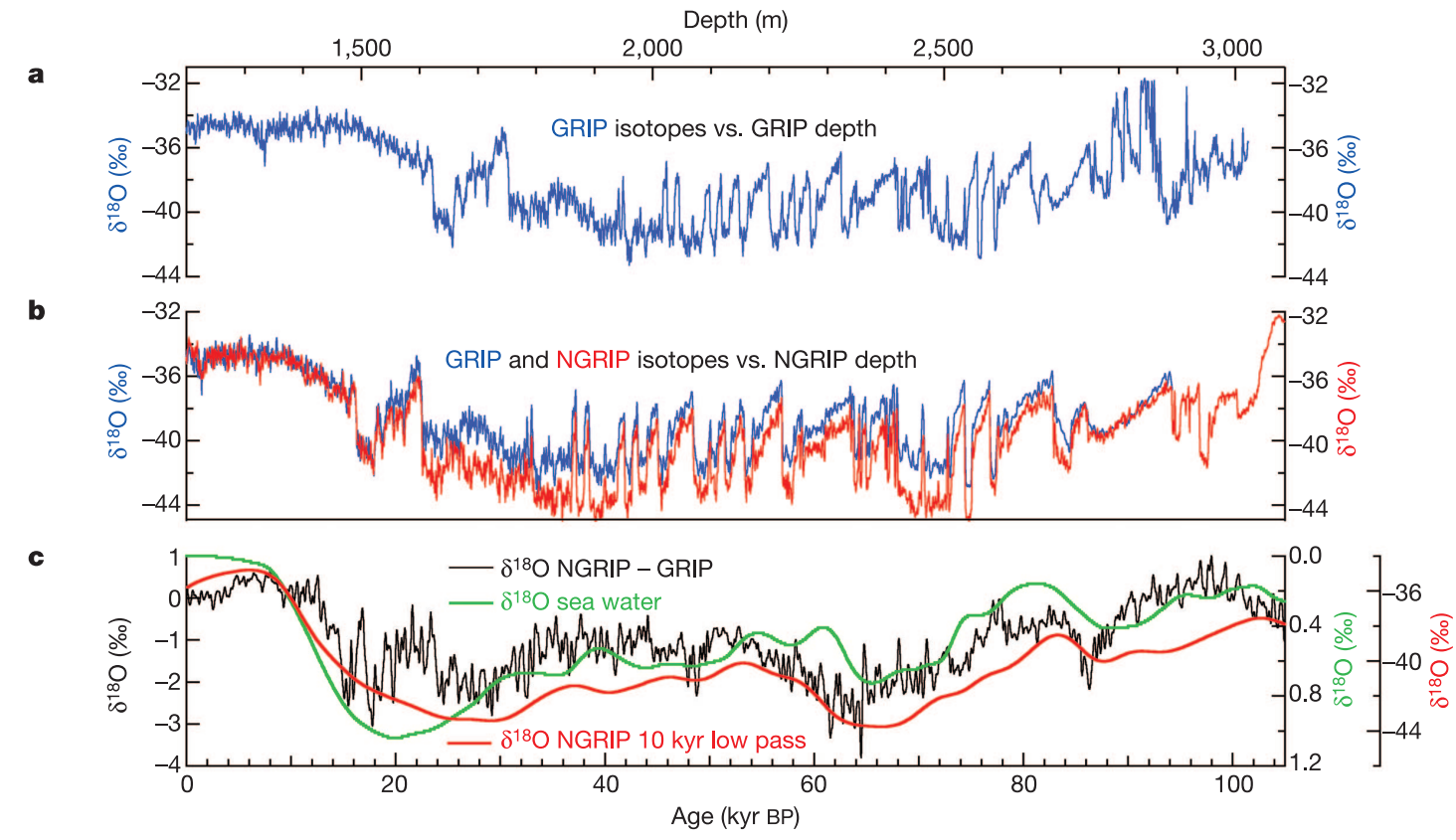

Figure 2 The NGRIP stable oxygen isotopic record compared to the GRIP record. a, The GRIP oxygen isotopic profile (blue) with respect to depth at GRIP. Isotopic values $\left(\delta^{18} 0\right)$ are expressed in \%o with respect to Vienna Standard Mean Ocean Water (V-SMOW). The measurements have been performed on $55 \mathrm{~cm}$ samples with an accuracy of $\pm 0.1 \%$. b, The NGRIP oxygen isotopic profile (red) with respect to depth at NGRIP. For comparison, the GRIP record (blue) has been plotted on the NGRIP depth scale using the rapid transitions as tie points. c, The difference between the NGRIP and GRIP oxygen isotopic profiles plotted above on the GRIP2001/ss09sea timescale ${ }^{15}$ in $50 \mathrm{yr}$ resolution (black). The record is compared to a record representing sea level changes ${ }^{39}$ (green) and a 10-kyr smoothed oxygen isotope profile from NGRIP (red). 
cores nearer the coast, such as Camp Century $\left(77.2^{\circ} \mathrm{N}, 61.1^{\circ} \mathrm{W}\right)$ in the west ${ }^{15}$, and Renland $\left(71.3{ }^{\circ} \mathrm{N}, 26.7^{\circ} \mathrm{W}\right)$ in the east ${ }^{15}$. We conclude that the relative elevation differences during the Eemian in northern Greenland are thus not large, and further, as the Renland ice cap only is $325 \mathrm{~m}$ thick and cannot change elevation by more than $100 \mathrm{~m}$, the absolute elevation changes between the Eemian and the present can only be of the order of $100 \mathrm{~m}$. In contrast, the Dye3 ice core in south Greenland $\left(65.2^{\circ} \mathrm{N}, 43.8^{\circ} \mathrm{W}\right)$ has an isotope difference of $5 \%$ (ref. 15), suggesting as much as $500 \mathrm{~m}$ lower elevation there. The Eemian isotopic values reported here paint a picture of an Eemian ice sheet with northern and central ice thicknesses similar to the present, while the south Greenland ice thickness is substantially reduced. This provides a valuable constraint for both future glaciological models of the Greenland Eemian ice sheet as well as models of sea level changes ${ }^{30,34-36}$.

\section{Climate record of the glacial inception}

This high resolution NGRIP record reveals a slow decline in temperatures from the warm Eemian isotopic values to cooler, intermediate values over 7,000 yr from 122 to $115 \mathrm{kyr}$ BP. The end of the last interglacial thus does not appear to have started with an abrupt climate change, but with a long and gradual deterioration of climate. Before full glacial values are reached, however, the record does reveal an abrupt cooling, with a first $\delta^{18} \mathrm{O}$ decrease at about $119 \mathrm{kyr}$ BP, followed by relatively stable depleted $\delta^{18} \mathrm{O}$ levels, which we name here the Greenland stadial 26. The stadial is followed by an abrupt increase at $\sim 115 \mathrm{kyr}$ BP, the onset of DO $25^{37}$ (Fig. 4). NGRIP is the first ice core climate record to so clearly resolve these rapid and large fluctuations in climate right at the beginning of the full glacial period. It is remarkable how well the features of the record compare with the marine planktonic isotope record from the margin of the Iberian coast, a proxy for the sea surface temperatures here. The features are thus believed to be large-scale features typical of the North Atlantic region $^{38}$. It is significant that DO 25, while weak (with an amplitude 25\% of the following DO events), was similar in character to the following DO events, although it occurred at the time when the ice caps were first building up. Thus it seems difficult to call on melting ice or other large freshwater input to the North Atlantic to trigger this event, although clearly we need more information from this and future ice cores to fully understand this first abrupt climate change of the last glacial.

\section{Regional climate differences in Greenland}

We now focus on a detailed comparison of the NGRIP $\delta^{18} \mathrm{O}$ ice profile with the GRIP ice isotopic record over their common part. Despite being only $325 \mathrm{~km}$ apart, these records have significant differences that illustrate the importance of regional variations in Greenland climate, even on quite long timescales. Figure $2 b$ shows the NGRIP ice isotope profile. The GRIP record shown in Fig. 2a is plotted on the NGRIP depth scale using the DO events as references, so the two records can be compared. At first glance, the two records are very similar as expected, given the relative proximity of the cores. But closer inspection shows substantial differences between the records. Whereas NGRIP and GRIP have very similar $\delta^{18} \mathrm{O}$ levels during the Holocene, glacial isotopic levels in the NGRIP record are systematically depleted by $1 \%$ o to $2 \%$. The difference between these isotopic profiles (Fig. 2c) reaches maxima at about 1520 kyr BP, 25-30 kyr BP and 60-70 kyr BP. The magnitude of the difference appears to be related to the Northern Hemisphere climate curve, as represented by a smoothed version of the NGRIP record, such that colder conditions have larger differences (Fig. 2c). The difference curve also compares relatively well to the global sea level curve $^{39}$, implying that the extent of the glacial continental ice sheets may help to explain the difference.

The difference curve only weakly traces the DO events, suggesting that the differences are not very well connected to processes operating on millennial timescales. A preliminary reconstruction of past temperatures based on the measured borehole temperatures

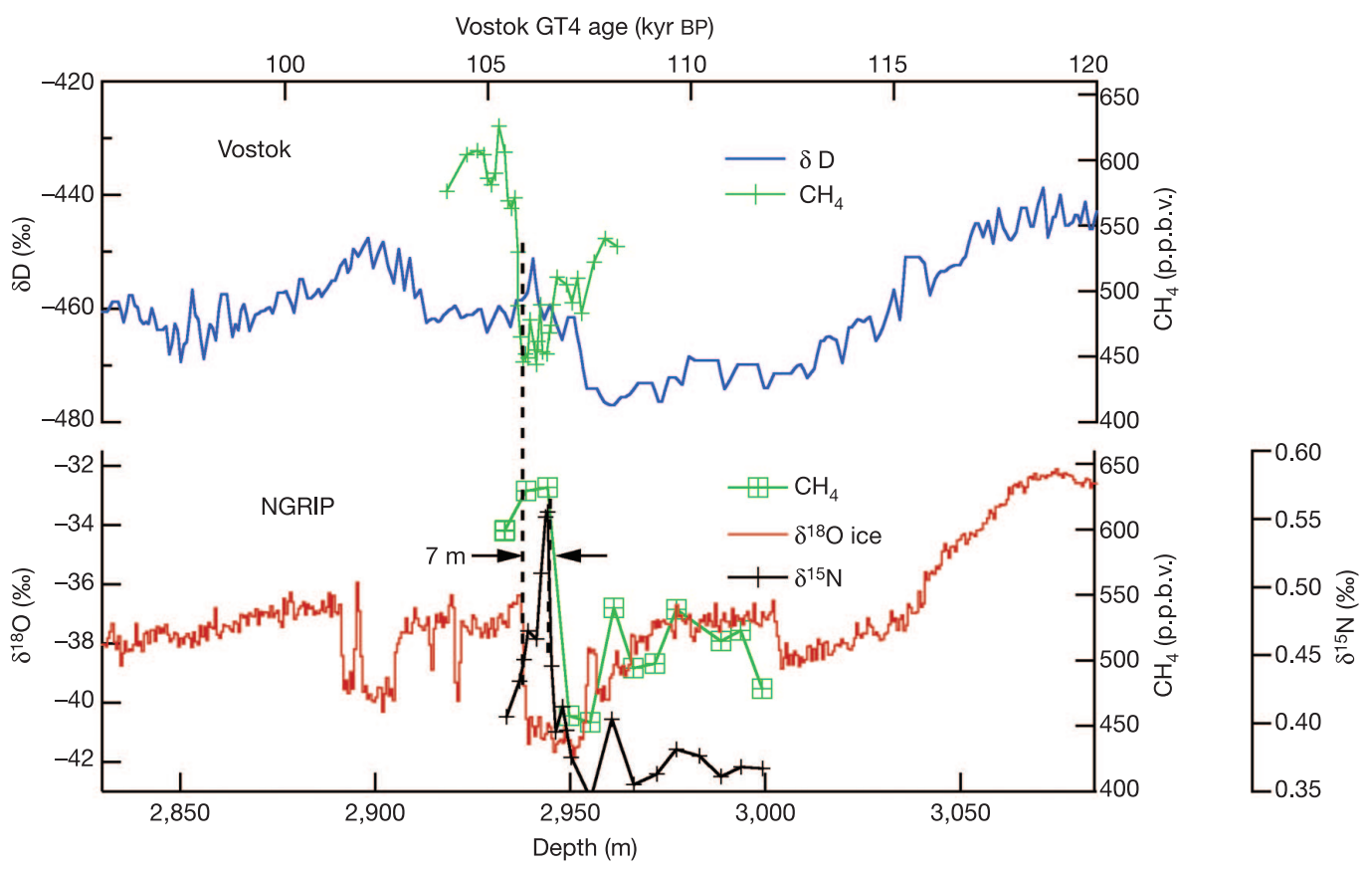

Figure 3 Comparison of ice core records from NGRIP and Vostok for NGRIP depths 2,830 to $3,085 \mathrm{~m}$. The isotopic composition, $\delta \mathrm{D}$, of the ice (blue) and of methane in the air (green) for Vostok are on the top, and the isotopic composition, $\delta^{18} 0$, of the ice (red), methane (green) and $\delta^{15} \mathrm{~N}$ (black) of the air for NGRIP are on the bottom. A 50-kyr resolution NGRIP record is available as Supplementary Information. The detailed Vostok methane profile combines published data and recent measurements performed to

examine the $5 \mathrm{~d} / 5 \mathrm{c}$ transition at Vostok ${ }^{24}$. The Vostok and NGRIP data are reported on their own scales, namely the GT4 timescale for Vostok (top axis) and the depth scale for NGRIP (bottom axis). These two independent scales have been simply shifted in order to match the sharp methane shift in Vostok with the sharp NGRIP warming at 2,940 m.

Furthermore, matching of the two scales should result in the estimated mean $1.1 \mathrm{~cm}$ annual layer thickness for the NGRIP profile. 
at NGRIP supports this finding. Temperatures reconstructed at NGRIP during the Last Glacial Maximum are several degrees colder than those at GRIP and GISP2. The observed isotopic differences are large, given the relatively small distance between the two sites, and our finding that the two sites are believed to have only undergone small relative elevation changes during the glacial period ${ }^{34,40}$. Whereas the isotopic records in the central parts of East Antarctica ${ }^{41}$ are rather similar and thus do not reveal large and significant climatically driven differences, the Greenland sites, located just $325 \mathrm{~km}$ apart, reveal major differences. Now that we are beginning to have a spatial distribution of deep ice core records, this brings into play a new source of palaeoclimatic information for these deep ice cores, that is, changes in geographical gradients with time. Our best theory is to postulate that the air masses reaching the two sites during the glacial had different sources. In response to the extent of the Laurentide ice sheet, sea ice and the extensive North Atlantic ice shelves, NGRIP has become further from the ocean, and may have seen a higher fraction of air coming over the northern side of the Laurentide ice sheet, bringing with it colder and more isotopically depleted moisture than GRIP might have seen ${ }^{42,43}$. Taken as a whole, the findings here suggest that the atmospheric water cycle over Greenland is substantially different between modern and glacial worlds.

\section{Basal water under the ice}

When drilling was completed at NGRIP, basal water flooded the deepest $45 \mathrm{~m}$ of the bore hole. Although we knew from temperature profiles taken in 2001-02 that the base of the ice sheet was at or very near the pressure melting point, liquid water was not seen in radar profiles done during site selection. The melt rate at the base at NGRIP is $7 \mathrm{~mm}^{\text {ice }} \mathrm{yr}^{-1}$, so the geothermal heat flow appears to be as high as $140 \mathrm{~mW} \mathrm{~m}^{-2}\left(70 \mathrm{~mW} \mathrm{~m}^{-2}\right.$ from latent heat, and $70 \mathrm{~mW} \mathrm{~m}^{-2}$ conducted though the ice based on the measured bore temperature). This high geothermal heat flow value is atypical for Precambrian shields ${ }^{44}$ believed to cover most of Greenland. The recent indications of bacterial life in and under Antarctic ice ${ }^{45}$ have revealed that the Earth possibly contains a previously unrecognized cold biosphere that would be actively involved in biogeochemical processes. Thus Greenland, like Antarctica, is now known to have
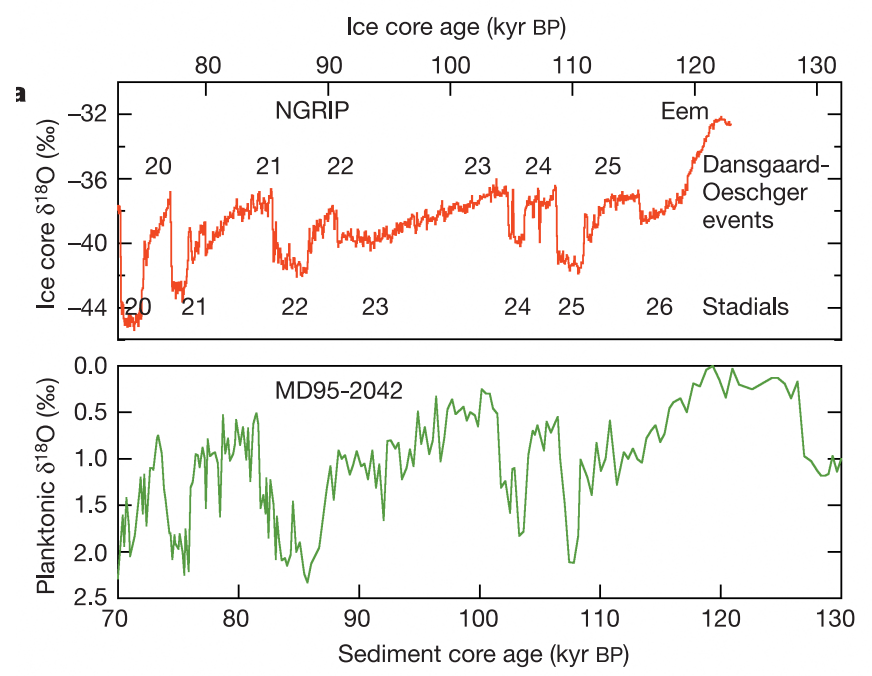

Figure 4 The NGRIP isotopic profile from the Supplementary Information (a) compared with the planktonic isotopes in the Iberian margin sediment core MD95-2024 ${ }^{29}(\mathbf{b})$. The Greenland Dansgaard-Oeschger events (interstadials) are numbered along with the associated stadials. The two age scales are independent and seem to match within a few kyr. liquid water at its base in some locations, water that awaits further study for basal sediment composition and evidence of life in a truly extreme environment.

\section{Implications for future palaeoclimatic studies}

The first measurements available on the NGRIP core already provide a wealth of new and promising environmental information. Most importantly, the NGRIP core contains the first continuous record of the late Eemian and the interception of the last glacial period to be recorded in a deep Greenland ice core. The palaeoclimatic signal for Greenland now reaches 123,000 yr back in time, and reveals a stable and warm late Eemian period. The end of the Eemian is a slow decline to glacial, cooler, intermediate conditions, but the onset of abrupt climate changes, the DO events that mark the last glacial period, precedes full glacial conditions. The bottom ice at NGRIP is essentially undisturbed and annual ice layers are quite thick, a situation caused by basal melting which in turn results from an unexpectedly high geothermal heat flow in North Greenland. The additional knowledge that the central and northern ice sheet during the Eemian period was at the same elevation as present constrains modelled ice volumes and sea level changes during the Eemian and glacial period. This interpretation is only consistent with modelling studies of the ice sheet during the Eemian that, although predicting an overall smaller ice sheet in accord with higher observed sea levels during this time ${ }^{34,35,46-48}$, allow for no large ice elevation change for the central Greenland ice. The next generation of models of the Greenland ice sheets should also include substantial melt under the northern part of the ice sheet as well as the northeast ice stream, important for the mass balance of the ice sheet ${ }^{49,50}$.

The deepest ice should allow a detailed study of the last glacial inception, including greenhouse gases and atmospheric dust loading, and in future comparisons with Antarctic records we should be able to investigate in detail the sequence of climatic events and forcing between north and south during this key climatic period. We find that the $5 \mathrm{~d} / 5 \mathrm{c}$ Vostok time period is the counterpart of the Northern Hemisphere stadial 25 that ends with the abrupt onset of DO 24 at the NGRIP depth 2,940 m. The north-south teleconnection observed here is similar in behaviour to all the following events (DO events 1-23), and behaves as predicted by the simple thermodynamic see-saw model ${ }^{23}$. In contrast, the weak stadial 26 followed by the abrupt onset of DO 25 is not opposed by an Antarctic reversal. This could be due to dating uncertainties between the two cores, but it could also be information on the timing of the onset of the teleconnection during the building of the ice caps and the cooling of the climate. When did the north-south climate see-saw begin? Is there information waiting to be found that can tell us how glacial periods begin, and whether we are in danger of entering one in the near future? New and detailed measurements from the EPICA Antarctica ice cores are expected to clarify this observation. And finally, is there life at the base of the Greenland ice sheet? These are some of the many questions that await further study of the new NGRIP ice core.

Received 5 March; accepted 30 June 2004; doi:10.1038/nature02805.

1. Johnsen, S. J. et al. Irregular glacial interstadials recorded in a new Greenland ice core. Nature 359, 311-313 (1992).

2. Dansgaard, W. et al. Evidence for general instability of past climate from a 250-kyr ice-core record. Nature 364, 218-220 (1993).

3. Greenland Ice-Core Project (GRIP) Members. Climate instability during the last interglacial period recorded in the GRIP ice core. Nature 364, 203-208 (1993).

4. Grootes, P. M., Stuiver, M., White, J. W. C., Johnsen, S. J. \& Jouzel, J. Comparison of oxygen isotope records from the GISP2 and GRIP Greenland ice cores. Nature 366, 552-554 (1993).

5. Taylor, K. C. et al. Electrical conductivity measurements from the GISP2 and GRIP Greenland ice cores. Nature 366, 549-552 (1993).

6. Bender, M. et al. Climate correlations between Greenland and Antarctica during the last 100,000 years. Nature 372, 663-666 (1994).

7. Fuchs, A. \& Leuenberger, M. $\delta^{18} \mathrm{O}$ of atmospheric oxygen measured on the GRIP Ice Core document stratigraphic disturbances in the lowest 10\% of the core. Geophys. Res. Lett. 23, 1049-1052 (1996).

8. Johnsen, S. J. et al. The $\delta^{18} \mathrm{O}$ record along the Greenland Ice Core Project deep ice core and the 
problem of possible Eemian climatic instability. J. Geophys. Res. 102, 26397-26410 (1997).

9. Chappellaz, J., Brook, E., Blunier, T. \& Malaizé, B. $\mathrm{CH}_{4}$ and $\delta^{18} \mathrm{O}$ of $\mathrm{O}_{2}$ records from Antarctic and Greenland ice: A clue for stratigraphic disturbance in the bottom part of the Greenland Ice Core Project and Greenland Ice Sheet Project 2 ice cores. J. Geophys. Res. 102, 26547-26557 (1997). 10. Dahl-Jensen, D. et al. The NorthGRIP deep drilling program. Ann. Glaciol. 35, 1-4 (2002).

11. Dahl-Jensen, D. et al. A search in north Greenland for a new ice-core drill site. J. Glaciol. 43, 300-306 (1997).

12. Dahl-Jensen, D., Gundestrup, N., Gorgineni, P. \& Miller, H. Basal melt at NorthGRIP modeled from borehole, ice-core and radio-echo sounder observations. Ann. Glaciol. 37, 207-212 (2003).

13. Alley, R. B. et al. Comparison of deep ice cores. Nature 373, 393-394 (1995).

14. Grinsted, A. \& Dahl-Jensen, D. A Monte Carlo-tuned model of the flow in the NorthGRIP area. Ann Glaciol. 35, 527-530 (2002).

15. Johnsen, S. J. et al. Oxygen isotope and palaeotemperature records from six Greenland ice-core stations: Camp Century, Dye-3, GRIP, GISP2, Renland and NorthGRIP. J. Quat. Sci. 16, 299-307 (2001).

16. Clausen, H. B. et al. A comparison of the volcanic records over the past 4000 years from the Greenland Ice Core Project and Dye3 Greenland ice cores. J. Geophys. Res. 102, 26707-26723 (1997).

17. Blunier, T. et al. Asynchrony of Antarctic and Greenland climate change during the last glacial period. Nature 394, 739-743 (1998)

18. Landais, A. et al. A tentative reconstruction of the last interglacial and glacial inception in Greenland based on new gas measurements in the Greenland Ice Core Project (GRIP) ice core. J. Geophys. Res. 108, doi:10.1029/2002JD0003147 (2003).

19. Flückiger, J. et al. $\mathrm{N}_{2} \mathrm{O}$ and $\mathrm{CH}_{4}$ variations during the last glacial epoch: Insight into global processes. Glob. Biogeochem. Cycles 18, doi:10.1029/2003GB002122 (2004)

20. Suwa, M., von Fischer, J. \& Bender, M. Age reconstruction for the bottom part of the GISP2 ice core based on trapped methane and oxygen isotopes records. Geophys. Res. Abstr. 5, 07811 (2003).

21. Caillon, N. et al. Estimation of temperature change and of gas age-ice age difference, $108 \mathrm{kyr} \mathrm{BP}$, at Vostok, Antarctica. J. Geophys. Res. 106, 31893-31901 (2001).

22. Petit, J. R. et al. Climate and atmospheric history of the past 420,000 years from the Vostok ice core, Antarctica. Nature 399, 429-436 (1999).

23. Stocker, T. F. \& Johnsen, S. J. A minimum thermodynamic model for the bipolar seesaw. Paleoceanography 18, doi:10.1029/2003PA000920 (2003).

24. Caillon, N., Jouzel, J., Severinghaus, J. P., Chappellaz, J. \& Blunier, T. A novel method to study the phase relationship between Antarctic and Greenland climate. Geophys. Res. Lett. 30, doi:10.1029/ 2003GL017838 (2003).

25. Severinghaus, J. P., Sowers, T., Brook, E. J., Alley, R. B. \& Bender, M. L. Timing of abrupt climate change at the end of the Young Dryas interval from thermally fractionated gases in polar ice. Nature 391, 141-146 (1998)

26. Chappellaz, J. et al. Synchronous changes in atmospheric $\mathrm{CH}_{4}$ and Greenland climate between 40 and 8 kyr BP. Nature 366, 443-445 (1993)

27. Brook, E. J., Sowers, T. \& Orchardo, J. Rapid variations in atmospheric methane concentration during the past 110,000 years. Science 273, 1087-1091 (1996).

28. Schwander, J. et al. Age scale of the air in the Summit ice: Implication for glacial-interglacial temperature change. J. Geophys. Res. 102, 19483-19493 (1997).

29. Shackleton, N. J., Hall, M. A. \& Vincent, E. Phase relationships between millennial-scale events $64,000-24,000$ years ago. Paleoceanography $15,565-569$ (2000).

30. Cuffey, K. M. \& Marshall, S. J. Substantial contribution to sea-level rise during the last interglacial from the Greenland ice sheet. Nature 404, 591-594 (2000).

31. Johnsen, S., Dahl-Jensen, D., Dansgaard, W. \& Gundestrup, N. Greenland palaeotemperatures derived from GRIP bore hole temperature and ice core isotope profiles. Tellus B 47, 624-629 (1995).

32. Cuffey, K. M. et al. Large arctic temperature change at the Wisconsin-Holocene glacial transition. Science 270, 455-458 (1995).
33. Bennike, O. \& Boecher, J. Land biotas of the last interglacial/glacial cycle, Jameson Land, East Greenland. Boreas 23, 479-488 (1994).

34. Marshall, S. J. \& Cuffey, K. M. Peregrinations of the Greenland Ice Sheet divide in the last glacial cycle: Implications for central Greenland ice cores. Earth Planet. Sci. Lett. 179, 73-90 (2000).

35. Huybrechts, P. Sea-level changes at the LGM from ice-dynamic reconstructions of the Greenland and Antarctic ice sheets during the glacial cycles. Quat. Sci. Rev. 21, 203-231 (2002).

36. Gregory, J. M., Huybrechts, P. \& Raper, S. C. B. Threatened loss of the Greenland ice-sheet. Nature 428, $616(2004)$.

37. McManus, J. F., Oppo, D. W., Keigwin, L. D., Cullen, J. L. \& Bond, G. C. Thermohaline circulation and prolonged interglacial warmth in the North Atlantic. Quat. Res. 58, 17-21 (2002).

38. Khodri, M. et al. Simulating the amplification of orbital forcing by ocean feedbacks in the last glaciation. Nature 410, 570-573 (2001).

39. Waelbroeck, C. et al. Sea-level and deep water temperature changes derived from benthic foraminifera isotopic records. Quat. Sci. Res. 21, 295-305 (2002).

40. Reeh, N., Oerter, H. \& Thomsen, H. H. Comparison between Greenland ice-margin and ice-core oxygen-18 records. Ann. Glaciol. 35, 136-144 (2002).

41. Watanabe, O. et al. Homogeneous climate variability across East Antarctica over the past three glacial cycles. Nature 422, 509-512 (2003)

42. Charles, C. D., Rind, D., Jouzel, J., Koster, R. D. \& Fairbanks, R. G. Seasonal precipitation timing and ice core records. Science 269, 247-248 (1995).

43. Charles, C. D., Rind, D., Jouzel, J., Koster, R. D. \& Fairbanks, R. G. Glacial-interglacial changes in moisture sources for Greenland: Influences on the ice core record of climate. Science 263, 508-511 (1994)

44. Dawes, P. R. in Geology of Greenland (eds Escher, A. \& Watt, W. S.) 248-303 (The Geological Survey of Greenland, Denmark, 1976).

45. Petit, J. R., Alekhina, I. \& Bulat, S. A. in Lessons for Exobiology (ed. Gargaud, M.) (Springer, in the press)

46. Letréguilly, A., Huybrechts, P. \& Reeh, N. Steady-state characteristics of the Greenland ice sheet under different climates. J. Glaciol. 37, 149-157 (1991).

47. Letréguilly, A., Reeh, N. \& Huybrechts, P. The Greenland ice sheet through the last glacial-interglacial cycle. Palaeogeogr. Palaeoclimatol. Palaeoecol. 90, 385-394 (1991).

48. Kukla, G., McManus, J. F., Rousseau, D.-D. \& Chuine, I. How long and how stable was the Last Interglacial? Quat. Sci. Rev. 16, 605-612 (1997).

49. Fahnestock, M., Abdalati, W., Joughin, I., Brozena, J. \& Cogineni, P. High geothermal heat flow basal melt, and the origin of rapid ice flow in central Greenland. Science 294, 2338-2342 (2001).

50. Fahnestock, M. A. et al. Ice-stream-related patterns of ice flow in the interior of northeast Greenland. J. Geophys. Res. 106, 34035-34045 (2001).

Supplementary Information accompanies the paper on www.nature.com/nature.

Acknowledgements NGRIP is directed and organized by the Department of Geophysics at the Niels Bohr Institute for Astronomy, Physics and Geophysics, University of Copenhagen. It is supported by funding agencies in Denmark (SNF), Belgium (FNRS-CFB), France (IPEV and INSU/CNRS), Germany (AWI), Iceland (RannIs), Japan (MEXT), Sweden (SPRS), Switzerland (SNF) and the USA (NSF, Office of Polar Programs).

Competing interests statement The authors declare that they have no competing financial interests.

Correspondence and requests for materials should be addressed to D.D.-J. (ddj@gfy.ku.dk) or S.J.J. (sigfus@gfy.ku.dk).

K. K. Andersen', N. Azuma ${ }^{2}$, J.-M. Barnola ${ }^{3}$, M. Bigler', P. Biscaye ${ }^{5}$, N. Caillon' ${ }^{6}$, J. Chappellaz ${ }^{3}$, H. B. Clausen', D. Dahl-Jensen', H. Fischer7, J. Flückiger ${ }^{4}$, D. Fritzsche ${ }^{7}$, Y. Fujit ${ }^{8}$, K. Goto-Azuma ${ }^{8}$, K. Grønvold ${ }^{9}$, N. S. Gundestrup' ${ }^{1 *}$, M. Hansson ${ }^{10}$, C. Huber ${ }^{4}$, C. S. Hvidberg', S. J. Johnsen', U. Jonsell ${ }^{10}$, J. Jouzel ${ }^{6}$, S. Kipfstuhl' ${ }^{7}$, A. Landais ${ }^{6}$, M. Leuenberger ${ }^{4}$, R. Lorrain ${ }^{11}$, V. Masson-Delmotte ${ }^{6}$, H. Miller ${ }^{7}$, H. Motoyama ${ }^{8}$, H. Narita ${ }^{12}$, T. Popp ${ }^{13}$, S. O. Rasmussen', D. Raynaud ${ }^{3}$, R. Rothlisberger ${ }^{4}$, U. Ruth², D. Samyn11, J. Schwander ${ }^{4}$, H. Shoji ${ }^{14}$, M.-L. Siggard-Andersen', J. P. Steffensen', T. Stocker ${ }^{4}$, A. E. Sveinbjörnsdóttir ${ }^{15}$, A. Svensson', M. Takata ${ }^{2}$, J.-L. Tison ${ }^{11}$, Th. Thorsteinssonn ${ }^{16}$, 0. Watanabe ${ }^{8}$, F. Wilhelms ${ }^{7}$ \& J. W. C. White ${ }^{13}$

Affiliations for authors: 1, Niels Bohr Institute for Astronomy, Physics and Geophysics, University of Copenhagen, Juliane Maries Vej 30, DK-2100 Copenhagen OE, Denmark; 2, Nagaoka University of Technology, 1603-1 Kamitomioka-machi, Nagaoka 940-2188, Japan; 3, Laboratoire de Glaciologie et Géophysique de l'Environnement (CNRS), BP 96, 38402 St Martin d'Héres Cedex, France; 4, Climate and Environmental Physics, Physics Institute, University of Bern, Sidlerstrasse 5, CH-3012, Switzerland; 5, Lamont-Doherty Earth Observatory of Columbia University, Rte 9W - PO Box 1000, Palisades, New York 10964-8000, USA; 6, Institute Pierre Simon Laplace/ Laboratoire des Sciences du Climat et de l'Environnement, UMR CEA-CNRS, CE Saclay, Omme des Merisiers, 91191 Gir-Sur-Yvette, France; 7, Alfred-Wegener-Institute for Polar and Marine Research (AWI), Postfach 120161, D-27515 Bremerhaven, Germany; 8, National Institute of Polar Research, Kaga 1-9-10, Itabashi-ku, Tokyo 173-8515 Japan; 9, Nordic Volcanological Institute, Grensásvegur 50, 108 Reykjavik, Iceland; 10, Department of Physical Geography and Quaternary Geology, Stockholm University, S-106 91, Stockholm, Sweden; 11, Département des Sciences de la terre et de l'Environnement, Faculté des Sciences, CP 160/03, Université Libre de Bruxelles, 50 avenue FD Roosevelt, B1050 Brussels, Belgium; 12, Research Institute for Humanity and Nature, 335 Takashima-cho, Marutamachi-dori Kawaramachi nishi-iru, Kamigyo-ku, Kyoto 602-0878, Japan; 13, INSTAAR, Campus Box 450, University of Colorado, Boulder, Colorado 80309-0450, USA; 14, Kitami Institute of Technology, Koencho 165, Kitami, Hokkaido 090-8507 Japan; 15, Raunvísindastofnun Háskólans, Dunhagi 3, Iceland; 16, National Energy Authority, Grensásvegur 9, IS-108 Reykjavík, Iceland

${ }^{*}$ Deceased 